\title{
Model of Nursing Group Intervention based on Interpersonal Human Caring (IHC) Toward Psychological Needs of the Adolescent in the Orphanage
}

\author{
Dwi Ananto Wibrata ${ }^{1}$, Siti Nur Kholifah ${ }^{2}$, Nursalam ${ }^{3}$, Yoyok Bekti Prasetyo ${ }^{4}$ \\ ${ }^{1}$ Senior Lecturer in Emergency Nursing Departement, Health Polytechnic Ministry of Healht Surabaya, ${ }^{2}$ Senior \\ Lecturer in Community Nursing, Health Polytechnic Ministry of Healht Surabaya, ${ }^{3}$ Professor in Nursing, Nursing \\ Faculty, Universitas Airlangga Surabaya, ${ }^{4}$ Senior Lecturer in Community Nursing, Faculty of Health Science, \\ University of Muhammadiyah Malang
}

\begin{abstract}
Introduction. Live at the Orphanage with various facility limitations requires teenagers to develop according to the situation. The facts that exist in the Orphanage, orientation of meeting the youth group's needs are physical needs. Purpose. The study aimed to develop an interpersonal human caring (IHC) -based group nursing intervention model on adolescents' psychological needs in the Orphanage. The contribution of this research is to increase the psychological needs of adolescents so that adolescents are confident in carrying out activities even at the orphanage. Method. The method used is observational analytic. The sample is some teenagers who live in orphanages in Surabaya City and Sidoarjo Regency, taken by random cluster sampling, totaling 260 people. Research variables include predisposing factors and values of care, supporting aspects and environmental caring, driving factors, interpersonal behavior of adolescents' human caring, and psychological needs. Phase 2 research with the quasi-experimental method for model testing. The samples were some of the teenagers who lived in one of the orphanages in Surabaya and Sidoarjo, amounting to 32 people taken by simple random sampling. The instrument uses a questionnaire. Data analysis used descriptive analysis and model testing with Partial Least Square (PLS) software. Results and Discuss. The first stage of the study found that all indicators of the variables can explain the construct variables $(T>1,96)$. Path diagram analysis of all exogenous variables influences psychological needs. The second phase of paired t-test testing found differences in psychological needs before and after the trial model. Model of Nursing Group Intervention based on interpersonal human caring (IHC) can be usedto support physical needs for teenagers in the Orphanage $(\mathrm{p}<0,05)$. Every In the Orphanage needs added a Psychology as a consultant. Conclusion. The new scientific findings from this study were the formation of IHC-based group intervention models. This model can fulfill psychological needs in adolescents at the Orphanage. The conclusion that predisposing factors and values of care, supporting elements and caring environment, and driving factors are essential factors that can influence human affectionate interpersonal behavior. Implication. This behavior can improve the fulfillment of the psychological needs of adolescents in the Orphanage.
\end{abstract}

Keywords: model, intervention, care, adolescence, psychological needs.

\section{Introduction}

Life in an orphanage with limited facilities requires children to develop by the existing situation. Children in

\footnotetext{
Corresponding author

Yoyok Bekti Prasetyo

e-mail: yoyok@umm.ac.id
}

a physical, psychological, and social development phase need conducive environmental conditions and possible means. In the orphanage, the orientation of meeting the needs of the children of the orphanage, including the youth group, is physical needs. This can be seen in the donors' donations on average in the form of money and nine staples (groceries). This condition does not yet support the psychological needs of the residents of the 
orphanage.

The development of the adolescent group's personality has a special meaning because the teenager is not a child but also not an adult, so it needs special attention, especially on their psychological needs ${ }^{1}$.Fulfilling psychological needs is just as important as meeting physiological needs. Physiological needs that are not fulfilled, such as eating, drinking result in people getting sick. Likewise, when psychological needs are not met, it will result in feelings of dissatisfaction, frustration, and inhibition of growth and development of positive attitudes towards the community and itself, so that they feel insignificant in their lives ${ }^{2}$

Adolescents who live in orphanages are the target for nurses' performance in implementing nursing care at the group level. In this case, nurses have the responsibility to meet adolescents' needs, including their psychological needs ${ }^{3}$. Komara, in 2016 explained that self-confidence is positively related to adolescent learning achievement. The better the self-confidence, the better learning achievement ${ }^{4}$. Research by Komang et al. (2014) explains a relationship between academic self-concept and achievement motivation ${ }^{5}$. Social support is related to adjustment to adolescents in the orphanage $^{6}$. There was a relationship between selfconcept and the meaning of life for adolescents in the orphanage. Previous research results were not found on the psychological needs of adolescents in orphanages or other topics related to adolescents in the orphanage. Novelty, this study will develop a model of nursing care for youth groups in an orphanage to fulfill psychological needs by integrating behavior theory (Lawrence Green), Caring's theory (Jean Watson), and psychogenic needs theory (Murray). Research from Suryo in 2010explains that the orphanage managers' behavior is influenced by knowledge, experience, competence, costs, and facilities ${ }^{7}$. Ministry of Social Affairs Republic of Indonesia (2011) explained that the results of research that was carried out in six provinces in Indonesia showed that the management of the orphanage did not have adequate knowledge about the situation of children who should be cared for in an orphanage, and care that should ideally be accepted by children. Childcare Social Institutions function more as an institution that provides access to education for children rather than as a last alternative institution for childcare that cannot be cared for by their parents or family ${ }^{8}$.

The second theory that is integrated is the caring theory. Caring is defined as a deliberate act that brings a sense of security both physically and emotionally and a sincere attachment to another person or group of people ${ }^{9}$. Caring can also be interpreted as a nurse's care for clients in providing nursing care by providing support to clients, communicating well, and taking nursing actions as needed ${ }^{10}$. Caring needs to be done at the orphanage by the manager for all orphanage residents so that the function of the orphanage as a substitute for parental care can be realized to meet the needs of adolescents in the orphanage. The caring theory will be integrated with interaction theory by implementing interpersonal communication. This communication will result in transactions between two or more people so that a transaction will occur ${ }^{10}$. Caring's theory is integrated with King's theory of interaction because in providing nursing action, communication is needed so that the goal of fulfilling psychological needs can be achieved.

The results showed 6(six) indicators of psychological well-being, namely autonomy, environmental control, personal growth, positive relationships with others, life goals, and self-acceptance ${ }^{11}$. Murray explained that psychogenic needs consist of humility, affiliation, aggression, autonomy, improving the situation, selfdefense, respect, domination, self-assertion, avoiding danger, avoiding humiliation, nurturing attitude, order, play, rejection, compassion, sexual needs, and understanding needs ${ }^{12}$. Psychological needs in this study refer to Murray's psychogenic needs, but they are also tailored to adolescents' needs, especially those who live in orphanages.

The nursing care model that was built will encourage the fulfillment of their psychological needs in adolescents. This condition will impact personality maturity, a positive attitude towards the environment, and a spirit of independence ${ }^{13}$. Adolescents who have met their psychological needs will become qualified young people for the Indonesian nation's development. This study aims to develop a group nursing intervention model based on interpersonal human caring (IHC) on the psychological needs of adolescents in the orphanage. 


\section{Method}

The first phase of research used an observational analytic method to describe the influence between variables, mainly the variable that affects the fulfillment of psychological needs in orphanage adolescents. The first phase's design was cross-sectional, with the orphanage adolescents among Surabaya City (29 Orphanage) and Sidoarjo Regency (11 Orphanage) as a population. It counts around 620 adolescents by determining the sample size (rule of thumb) of 260 adolescents. The sampling methods used probability sampling. The sample selection is not based on the researcher's wishes, so that every member of the population has the same opportunity to be selected as a sample ${ }^{14}$. This first stage of research used random cluster sampling. The samples were determined by randomly selecting orphanages in each of the North, West, East, South, and Central Surabaya areas and the Sidoarjo region, so that 14 (fourteen) orphanages were assigned, 9 (nine) orphanages in the city of Surabaya and 5 ( Five) Orphanages in Sidoarjo Regency.

The method of processing the data that has been obtained is by doing: 1) editing, namely checking the completeness, consistency, and suitability of the data that has been obtained; 2) coding to classify answers based on certain codes; 3) data entry, a list of questions that have been completed with the coding of answers, then processed by a computer so that it is ready for analysis; 4) cleaning, data cleaning if there is an error during data entry.

Data analysis was done descriptively and inferential. Descriptive data analysis was used to identify the factors that influence caring behavior in the orphanage. This descriptive analysis is carried out by creating a frequency distribution table and calculating the frequency or number and percentage of the measured aspects. The inferential analysis is used to test the empirical model and hypotheses proposed in this study.

This study's data collection tool was a questionnaire developed from research variables using a Likert scale. Each sub variable consists of five statements with the choice of answers strongly agree (SS), agree (S), disagree (TS), and strongly disagree (STS). The results of the research questionnaire validity test showed that all the question items were valid. The results of the questionnaire reliability test showed that all questionnaires were reliable with a value $>0.7$.

The analysis technique used is a structural equation model (Structural Equation Modeling-SEM) based on variance or component-based SEM, known as Smart Partial Least Square version 2.0 (Smart PLS, 2.0). Explanatory research used as the second phase in quasi-experimental design aimed to explain the group nursing care model to fulfill adolescents' psychological needs in an orphanage. This phase is used to assess the psychological fulfillment before model simulation (pretest) then evaluate it after simulation (post-test). This design was used without a control group with paired t-test as statistical analysis.

The second stage uses explanatory research that aims to describe the model of group nursing care to meet adolescents' psychological needs in the orphanage. The second stage of research was Quasy experimental. The second stage is to simulate the nursing care model in the group. Simulations are carried out after the modules are structured, and the caregivers/managers of the orphanage have been given training on simulated models. The samples in the second phase of research were adolescents who lived in orphanages where the caregivers had attended training, namely the Khadijah 2 Orphanage Surabaya and the Al-Muttahidin Orphanage in Sidoarjo. Sampling using probability sampling techniques. The number of samples is 32 people.

The simulation results are used to assess the psychological needs of adolescents in the orphanage. The orphanage selected for the simulation has assessed the fulfillment of psychological needs first (pretest), and after that, a re-evaluation (post-test) was carried out. The designs used were pretest and post-test designs without a control group.Ethical clearance this study from the Research Ethics Commission of Politeknik Kesehatan Kemenkes Surabaya No. 183/5 / KEPK / VI / 2018.

\section{Results and Discussion}

\section{Results of the first phase}

The description of the characteristics of adolescents living in the orphanage is as follows. 
Table 1. Table of Distribution of Characteristics of Adolescents in Orphanages inInterpersonal Human Caring-based Group Nursing Intervention Modeling of Adolescents' Psychological Needs in Orphanages.

\begin{tabular}{|c|c|c|c|c|}
\hline No & & Characteristic & Account & Percentage \\
\hline 1 & $\begin{array}{l}\text { a. } \\
\text { b. } \\
\text { c. }\end{array}$ & $\begin{array}{l}\text { Age } \\
10-14 \text { year } \\
15-17 \text { year } \\
>17 \text { year }\end{array}$ & $\begin{array}{c}101 \\
100 \\
59\end{array}$ & $\begin{array}{l}38,8 \\
38,5 \\
22,7\end{array}$ \\
\hline 2 & $\begin{array}{l}\text { a. } \\
\text { b. }\end{array}$ & $\begin{array}{l}\text { Sex } \\
\qquad \text { Male } \\
\text { Female }\end{array}$ & $\begin{array}{l}119 \\
141\end{array}$ & $\begin{array}{l}46 \\
54\end{array}$ \\
\hline 3 & $\begin{array}{l}\text { a. } \\
\text { b. } \\
\text { c. } \\
\text { d. }\end{array}$ & $\begin{array}{c}\text { Education } \\
\text { SD } \\
\text { SMP } \\
\text { SMU } \\
\text { PT }\end{array}$ & $\begin{array}{c}18 \\
106 \\
105 \\
31\end{array}$ & $\begin{array}{c}6,9 \\
40,8 \\
40,4 \\
11,9\end{array}$ \\
\hline 4 & $\begin{array}{l}\text { a. } \\
\text { b. } \\
\text { c. }\end{array}$ & $\begin{array}{l}\text { Length of stay at the orphanage }<\mathbf{1} \text { Tahun } \\
\qquad \begin{aligned} 1-5 \text { year } \\
6-10 \text { year } \\
11-16 \text { year }\end{aligned}\end{array}$ & $\begin{array}{c}7 \\
163 \\
74 \\
16\end{array}$ & $\begin{array}{c}2,7 \\
62,7 \\
28,5 \\
6,1\end{array}$ \\
\hline 5 & $\begin{array}{l}\text { a. } \\
\text { b. } \\
\text { c. }\end{array}$ & $\begin{array}{l}\text { Etnic } \\
\text { Jawa } \\
\text { Madura } \\
\text { others }\end{array}$ & $\begin{array}{c}228 \\
22 \\
10\end{array}$ & $\begin{array}{l}87,7 \\
8,5 \\
3,8\end{array}$ \\
\hline
\end{tabular}

Based on table 1, the adolescent age group in this research between early and middle adolescents has almost the same percentage. Most of the total adolescents are female (54\%). Adolescents who attend junior and senior high schools have almost the same percentage. Most of the length of stay in the orphanage is between $1-5$ years $(62.7 \%)$. Most of the adolescents are Javanese (87.7\%).

Dimension of Predisposing Factors and Value of Care (X1) and Human Caring Interpersonal Factors (X4)
The predisposing factors and the value of care are constructed by 3 (three) indicators, namely the attitude of the orphanage manager (X1.1), the motivation of the orphanage (X1.2), and the commitment of the orphanage manager X1.3). The results can be seen in the table below:

Table 2. Distribution of Frequency Predispositions and Values of Care (X1) and HumanCaringInterpersonal Human Caring-based Group Nursing Intervention Modeling of Adolescents' Psychological Needs in Orphanages. 
Table 2 explains that the management commitment indicator has the largest percentage of the under category $(3.8 \%)$ among the other indicators. The indicator of health education has the highest percentage $(37.7 \%)$ in the low category.

\begin{tabular}{|c|c|c|c|c|c|c|c|c|c|}
\hline \multirow{3}{*}{ No. } & \multirow{3}{*}{ Indicator } & \multicolumn{6}{|c|}{ Category } & \multirow{2}{*}{\multicolumn{2}{|c|}{ Total }} \\
\hline & & \multicolumn{2}{|c|}{ Good } & \multicolumn{2}{|c|}{ Enough } & \multicolumn{2}{|c|}{ Less } & & \\
\hline & & $\mathbf{n}$ & $\%$ & $\mathbf{N}$ & $\%$ & $\mathbf{n}$ & $\%$ & $\mathbf{n}$ & $\%$ \\
\hline \multicolumn{10}{|c|}{ Dimension of Predisposing Factors and Value of Care (X1) } \\
\hline 1. & $\begin{array}{l}\text { The attitude of the orphanage } \\
\text { administrator }\end{array}$ & 139 & 53,5 & 119 & 45,8 & 8 & 0,8 & 260 & 100 \\
\hline 2. & $\begin{array}{l}\text { Motivation of the orphanage } \\
\text { administrators }\end{array}$ & 85 & 32,7 & 172 & 66,2 & 3 & 1,2 & 260 & 100 \\
\hline 3. & $\begin{array}{c}\text { Commitment of the orphanage } \\
\text { management }\end{array}$ & 151 & 58,1 & 99 & 38,1 & 10 & 3,8 & 260 & 100 \\
\hline \multicolumn{10}{|c|}{ Human Caring Interpersonal Factors (X4) } \\
\hline 4. & Interpersonal communication & 55 & 21,2 & 204 & 78,5 & 1 & 0,4 & 260 & 100 \\
\hline 5. & Group health education & 33 & 12,7 & 129 & 49,6 & 98 & 37,7 & 260 & 100 \\
\hline 6. & The act of parenting & 108 & 41,5 & 145 & 55,8 & 7 & 2,7 & 260 & 100 \\
\hline 7. & $\begin{array}{l}\text { Actions for improve taste } \\
\text { confidence }\end{array}$ & 57 & 21,9 & 185 & 71,2 & 18 & 6,9 & 260 & 100 \\
\hline
\end{tabular}

Supporting Factors and Caring Environment (X2), and driving factor (X3)

Supporting factors and caring environment (X2) is constructed by four indicators, namely learning facilities (X2.1), socialization facilities (X2.2), counseling facilities (X2.3), and opportunities to develop achievement (X2.4). Human Caring Interpersonal
Factors (X4) is constructed by three indicators, namely interpersonal communication (X4.1), group health education (X4.2), parenting actions (X4.3), and actions to increase self-confidence (X4.4).The results can be seen in the table below: 
Table 3. Frequency Distribution of Supporting Factors and Caring Environment, and driving factor (X3) in Interpersonal Human Caring-based Group Nursing Intervention Modeling of Adolescents' Psychological Needs in Orphanages.

\begin{tabular}{|c|c|c|c|c|c|c|c|}
\hline \multirow{3}{*}{ No. } & \multirow{3}{*}{ Indicator } & \multicolumn{4}{|c|}{ Category } & \multirow{2}{*}{\multicolumn{2}{|c|}{ Total }} \\
\hline & & \multirow{2}{*}{$\frac{\text { Good }}{n}$} & \multirow[b]{2}{*}{$\%$} & \multirow{2}{*}{$\begin{array}{c}\text { Less } \\
\mathrm{n}\end{array}$} & \multirow[b]{2}{*}{$\%$} & & \\
\hline & & & & & & $\mathbf{n}$ & $\%$ \\
\hline \multicolumn{8}{|c|}{ Supporting Factors and Caring Environment (X2) } \\
\hline 1. & Learning facilities & 140 & 53,8 & 120 & 45,2 & 260 & 100 \\
\hline 2. & Socialization facilities & 184 & 70,8 & 76 & 29,2 & 260 & 100 \\
\hline 3. & Counseling facilities & 100 & 38,5 & 160 & 61,5 & 260 & 100 \\
\hline 4. & Opportunity to develop achievements & 73 & 28,1 & 187 & 71,9 & 260 & 100 \\
\hline \multicolumn{8}{|c|}{ Driving factor (X3) } \\
\hline 5. & Orphanage management system & 236 & 90,8 & 24 & 9,2 & 260 & 100 \\
\hline 6. & Family support & 183 & 70,4 & 77 & 29,6 & 260 & 100 \\
\hline 7. & Community support & 147 & 56,5 & 113 & 43,5 & 260 & 100 \\
\hline
\end{tabular}

Table 3 explains that the indicator of the opportunity to develop achievement has the smallest percentage $(28.1 \%)$ in the good category. The driving factor (X3) is constructed by three indicators, namely the orphanage management system (X3.1), family support (X3.2), and community support (X3.3). The community support indicator has the greatest percentage in the lower category $(43.5 \%)$.

Fulfilling the Psychological Needs of Youth in an Orphanage (Y)

Table 4. Frequency Distribution of Psychological Needs Fulfillment in Interpersonal Human Caring-based Group Nursing Intervention Modeling of Adolescent Psychological Needs in Orphanages.

\begin{tabular}{|c|c|c|c|c|c|c|c|c|c|}
\hline \multirow{3}{*}{ No. } & \multirow{3}{*}{ Indicator } & \multicolumn{6}{|c|}{ Category } & \multirow{2}{*}{\multicolumn{2}{|c|}{ Total }} \\
\hline & & \multicolumn{2}{|c|}{ Good } & \multicolumn{2}{|c|}{ Enough } & \multicolumn{2}{|c|}{ Less } & & \\
\hline & & $\mathbf{n}$ & $\%$ & $\mathbf{N}$ & $\%$ & $\mathbf{n}$ & $\%$ & $\mathbf{n}$ & $\%$ \\
\hline 1. & Need of chievement & 59 & 22,7 & 120 & 46,2 & 81 & 31,2 & 260 & 100 \\
\hline 2. & Need of Affiliation & 66 & 25,4 & 158 & 60,8 & 36 & 13,8 & 260 & 100 \\
\hline 3. & Need of Autonomy & 117 & 45 & 126 & 48,5 & 17 & 6,5 & 260 & 100 \\
\hline 4. & Need of Counteraction & 131 & 50,4 & 110 & 42,3 & 19 & 7,3 & 260 & 100 \\
\hline 5. & Need of Defendance & 68 & 26,2 & 169 & 65 & 23 & 8,8 & 260 & 100 \\
\hline 6. & Need of Deference & 115 & 44,2 & 126 & 48,5 & 19 & 7,3 & 260 & 100 \\
\hline 7. & Need of Order & 156 & 60 & 90 & 34,6 & 14 & 5,4 & 260 & 100 \\
\hline 8. & Need of Understanding & 111 & 42,7 & 136 & 52,3 & 13 & 5 & 260 & 100 \\
\hline
\end{tabular}

Fulfillment factor for adolescent psychological needs is constructed by Need of achievement (Y.1.1), Need of Affiliation (Y.1.2), Need of Autonomy (Y.1.3), Need of Counteraction (Improve the situation) (Y.1.4), Need of Defendants (Y.1.5), Need of Deference (Y.1.6), Need of Order (Y.1.7), Need of Understanding (Understanding) (Y.1.8). The research results can be seen in the table below: 


\section{Evaluation of measurement model (outer model)}

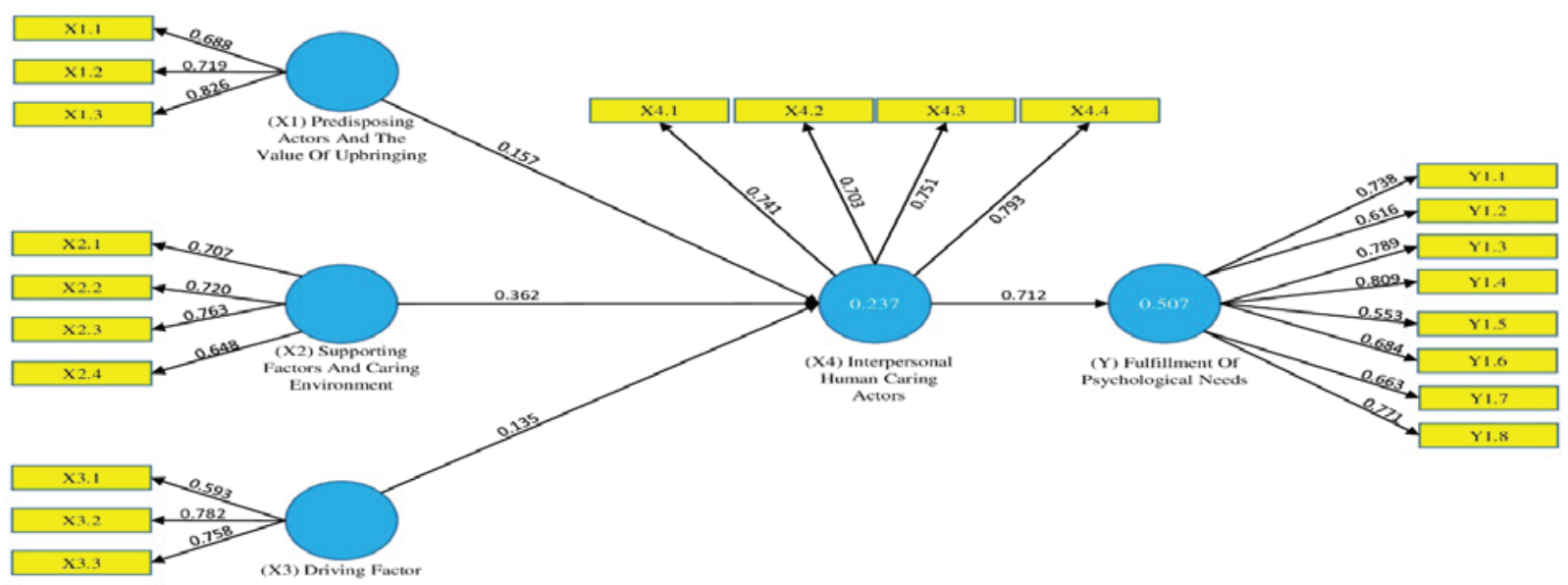

Figure 1. T-Statistical Path Diagram

Based on figure 1. above, it can be seen that some variables have a loading factor value of less than 0.7. Still, because the T-statistic value is more than 1.96 , the construct variables in the latent that are reflected do not have to be eliminated on the existing variables.

\section{Evaluation of Structural Model (Inner Model)}

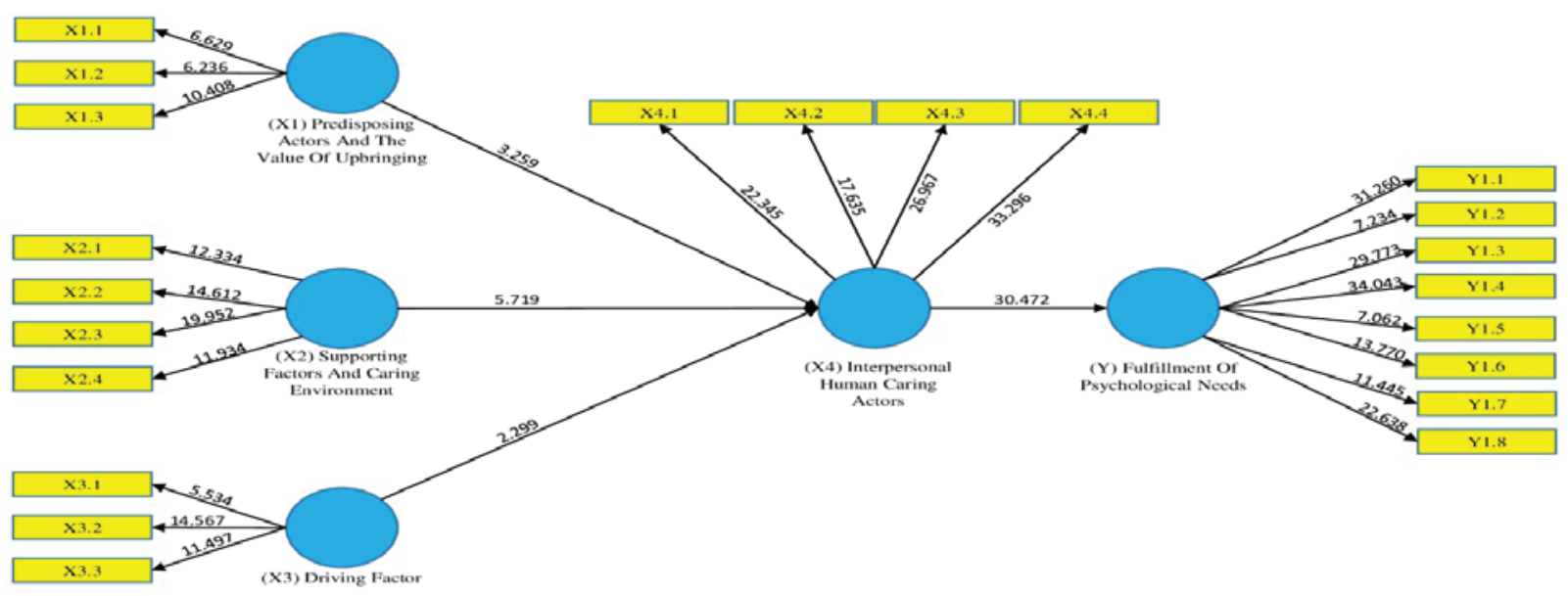

Figure 2. Structural Equation Path Diagram SEM Partial Least Square Against Indicators on Each Latent Variable in Interpersonal Human Caring-based Group Nursing Intervention Modeling of Adolescent Psychological Needs in Orphanages. 
The results of the significance test of exogenous variables on endogenous variables are described in table 5 .

Table 5. of Significance Analysis on Structural Model (Inner Model)

\begin{tabular}{|c|c|c|c|c|c|c|}
\hline Path & $\begin{array}{c}\text { Original } \\
\text { Sample } \\
(\mathbf{O})\end{array}$ & $\begin{array}{c}\text { Sample } \\
\text { Mean (M) }\end{array}$ & $\begin{array}{c}\text { Standard } \\
\text { Deviation } \\
(\mathbf{S T D E V})\end{array}$ & $\begin{array}{c}\text { T Statistics } \\
(|\mathbf{O} / \mathbf{S T D E V}|)\end{array}$ & $\begin{array}{c}\text { P } \\
\text { Values }\end{array}$ & Result \\
\hline $\begin{array}{c}\text { X1 Predisposing factors and } \\
\text { values of care -> X4 IHC } \\
\text { Behavior }\end{array}$ & 0.157 & 0.165 & 0.048 & 3.259 & 0.001 & Significant \\
\hline $\begin{array}{c}\text { X2 Supporting factorsandcaring } \\
\text { environment -> X4 interpersonal } \\
\text { human caring behaviors }\end{array}$ & 0.362 & 0.363 & 0.063 & 5.719 & 0.000 & Significant \\
\hline $\begin{array}{c}\text { X3 Driving factors -> X4 IHC } \\
\text { behaviors }\end{array}$ & 0.135 & 0.140 & 0.059 & 2.299 & 0.022 & Significant \\
\hline $\begin{array}{c}\text { X4 Interpersonal human caring } \\
\text { (IHC) behavior -> Y adolescent } \\
\text { psychological needs }\end{array}$ & 0.712 & 0.719 & 0.023 & 30.472 & 0.000 & Significant \\
\hline
\end{tabular}

Structural Equation Modeling test results with Partial Least Square based on the value of $\mathrm{R}^{2}$ note that the model of construct had a value with the model criteria according to Chin, 1998. The moderate strength model on the latent construct in each construct was a latent construct strong enough to describe the structural model concept.

\section{The goodness of Fit (GoF)}

Based on the GoF value of 0.473 , which that value was high and powerful, it might be noticed that the prediction model in this research is powerful in explaining the variables, or the significancy of thevariable effect is great/strong ${ }^{15}$.

\section{Results of the second phase}

The second stage of the study results were the trials of the Interpersonal Human Caring model on psychological fulfillment in adolescents in the orphanage.

Table 6. Psychological Needs Frequency Distribution between before and after of Model of Nursing Group Intervention Simulation based on Interpersonal Human Caring to Adolescent Psychological Needs in the Orphanage

\begin{tabular}{|c|c|c|c|c|}
\hline \multirow{2}{*}{ No. } & \multirow{3}{*}{ Indikator } & \multicolumn{3}{|c|}{ Category } \\
\cline { 2 - 4 } & Good & Moderate & Poor \\
\hline \multirow{4}{*}{1. Pre test } & Need of chievement & $8(25 \%)$ & $18(56,3 \%)$ & $6(18,7 \%)$ \\
\cline { 2 - 4 } & Need of Affiliation & $15(46,9 \%)$ & $16(50 \%)$ & $1(3,1 \%)$ \\
\cline { 2 - 5 } & Need of Autonomy & $15(46,9 \%)$ & $17(51,1 \%)$ & $0(0 \%)$ \\
\cline { 2 - 5 } & Need of Counteraction & $21(65,6 \%)$ & $11(34,4 \%)$ & $0(0 \%)$ \\
\cline { 2 - 5 } & Need of Defendance & $5(15,6 \%)$ & $27(84,4 \%)$ & $0(0 \%)$ \\
\cline { 2 - 5 } & Need of Deference & $18(56,2 \%)$ & $14(43,8 \%)$ & $0(0 \%)$ \\
\cline { 2 - 5 } & Need of Order & $23(71,9 \%)$ & $9(28,1 \%)$ & $0(0 \%)$ \\
\cline { 2 - 5 } & Need of Understanding & $8(25 \%)$ & $24(75 \%)$ & $0(0 \%)$ \\
\hline
\end{tabular}


Cont... Table 6. Psychological Needs Frequency Distribution between before and after of Model of Nursing Group Intervention Simulation based on Interpersonal Human Caring to Adolescent Psychological Needs in the Orphanage

\begin{tabular}{|c|c|c|c|c|}
\hline \multirow{8}{*}{ 2.Post Test } & Need of chievement & $13(40,6 \%)$ & $16(50 \%)$ & $3(9,4 \%)$ \\
\hline & Need of Affiliation & $21(65,6 \%)$ & $11(34,4 \%)$ & $0(0 \%)$ \\
\hline & Need of Autonomy & $25(78,1 \%)$ & $7(21,9 \%)$ & $0(0 \%)$ \\
\hline & Need of Counteraction & $27(84,4 \%)$ & $5(15,6 \%)$ & $0(0 \%)$ \\
\hline & Need of Defendance & $18(56,2 \%)$ & $14(43,8 \%)$ & $0(0 \%)$ \\
\hline & Need of Deference & $28(87,5 \%)$ & $4(1,25 \%)$ & $0(0 \%)$ \\
\hline & Need of Order & $27(84,4 \%)$ & $5(15,6 \%)$ & $0(0 \%)$ \\
\hline & Need of Understanding & $32(100 \%)$ & $0(0 \%)$ & $0(0 \%)$ \\
\hline
\end{tabular}

\section{Statistical analysis result of the second phase}

This research has shown that a minority of the Orphanage Caregiverswere low if viewed by the orphans from attitude, motivation, and commitment. The discussion with the caregiver somewhere causes anger or resentment.

Similar results stated by Ferris, K. in 1981 explained a relationship between commitment and individual performance $^{16}$. Based on the affective commitment dimension, the Orphanage Caregivers who love the profession resulted in the responsibility to do their work properly ${ }^{17}$. The commitment may affect the organization's performance ${ }^{18}$. Commitment is the crucial construct to retain trusted employees, knowledge, and the organization'sperformance ${ }^{19}$. The Orphanage Caregiver who comprehended the orphanage's vision might intend to do their job as well as possible to nurture and care for the orphans.

The result of statistical revealed $p=0,008$, which means there is a difference between adolescents' psychological needs before and after Model of Nursing Group Intervention Simulation based on interpersonal human caring (IHC).

\section{Discussion}

The interpersonal human caring-based group's application, the nursing intervention model, affects adolescents' psychological needs in the orphanage. The psychological needs of adolescents in this study refer to Murray's theory, which is adapted to the psychological development of adolescents ${ }^{20}$, consisting of the need for achievement, need of affiliation, need of autonomy, need of Counteraction (Improving the situation), need of defense, need of Deference (attitude of respect), need of order, and need of understanding. This psychological need is by the results of research by Van Dierendonck et al. in 2008, which explains that 6 (six) psychological well-being, namely autonomy, environmental control, personal growth, positive relationships with others, life goals, and self-acceptance ${ }^{11}$

The results of the research on the need for achievement were obtained from 260 adolescents as respondents, 120 people (46.2\%) of whom had sufficient psychological needs, 55 people $(22.7 \%)$ were good, and 81 people $(31.2 \%)$ were in the poor category. Based on the questionnaire data analysis, most of the adolescents had not been included in the competition according to their talents; most of them answered "sometimes" they were allowed to get special guidance and facilities to hone their talents. This fact is consistent with Komang Dyah L. and Putu N.'s research in 2014, explaining a relationship between academic self-concept and achievement motivation ${ }^{5}$. Youth in the orphanage are required to be able to adapt to facing a much competitive life. The success that is carved by adolescents or the failure that occurs when adolescents try to achieve can be a predictor of success as an adult ${ }^{21}$.

The research results on the psychological needs of affiliation found that most $(60.8 \%)$ were sufficient, $25.4 \%$ were good, and $13.8 \%$ were less. This need for collaboration is the need to socialize with friends and the 
environment. The results of the analysis of adolescent answers to the questionnaire found that caregivers/ administrators were still not optimal in facilitating adolescents to be involved in community organizations and providing facilities to access social media. Teens generally want to socialize with peers either directly or through social media. The results of this study reinforce the statement of Greca's research results. The social development of adolescents needs to be understood by parents and caregivers/administrators of the orphanage and those who serve as adolescent educators because the social development of adolescents has an important effect on adolescents' personality development and learning achievement.

The research results on the autonomy needs of adolescents found that $48.5 \%$ were sufficient, $45 \%$ were good, and $6.5 \%$ were in the poor category. The need for autonomy is a need for adolescents to be free to choose what actions to take. Van Dierendonck et al. in 2008stated that autonomy is an indicator of psychological well-being in adolescents ${ }^{11}$. Bartholemew et al. in 2011 explained that autonomy support affects need satisfaction ${ }^{22}$. Personal autonomy is a predictor of psychological satisfaction for adolescents. Autonomy (autonomy), is the need for a person to freely integrate actions carried out with oneself without being bound or controlled by others ${ }^{23}$. Steinberg in Ali M \& Asrori in 2018 distinguishes the characteristics of independence into three forms, namely: a) Emotional autonomy, which is an aspect of independence that states changes in the closeness of emotional relationships between individuals, such as emotional relationships between individuals, such as emotional relationships of students. With teachers or their parents. b) Behavioral autonomy, which is the ability to make decisions without depending on others and do them responsibly. c) Value autonomy, namely the ability to interpret a set of principles about right and wrong, about what is important and what is not. Factors such as rewards (rewards) or threats can reduce the need for an individual to be fully autonomous in his actions. Conditions such as being free to make choices or knowing the individual's feelings can increase satisfaction with the need for autonomy ${ }^{4}$.

The study results in need to improve the situation more than half $(50.4 \%)$ in the good category, $42.3 \%$ in the sufficient category, and $7.3 \%$ in the low category.
The need for Counteraction (Improving the situation) in this study is defined as the need for adolescents to improve failure, suppress feelings of fear, and maintain self-esteem ${ }^{12}$.

The questionnaire data analysis results of the orphanage administrators/caregivers have reconciled teenagers when fighting with other teenagers. Administrators/caregivers have also made it a habit to deliberate with adolescents before making decisions to increase youth self-esteem. Healthy youth self-esteem must be maintained in their immediate environment, such as an orphanage. Positive relationships with their friends will reinforce their sense of value to others.

The research results on self-defense need were mostly (65\%) in the moderate category, $26.2 \%$ in the good category, and $8.8 \%$ in the poor category. Defendants' need (Self-defense) in this study is to defend themselves against attacks, criticism, and reproach ${ }^{12}$. The results of data analysis from the list of questions given to adolescents found that caregivers sometimes provided the opportunity to reason/argue when adolescents were found guilty. The needs of adolescents in self-defense will be fulfilled when adolescents are given freedom of speech, freedom to take action as long as they do not harm others, freedom to explore the environment, justice, honesty, and fairness ${ }^{4}$.

The research results on the psychological need for respect were $48.5 \%$ in the sufficient category, $44.2 \%$ in the good category, and $7.3 \%$ in the poor category. The need for Deference (respect attitude) in this study is to respect and happily submit to the influence of others who are known. The questionnaire data analysis results showed that adolescents had given greetings, did not speak louder, and were reluctant to care for the orphanage caregivers/administrators. Respect in acting, speaking, and how to treat other people's belongings is a form of respect for others. The research results on the discipline component's psychological needs found that most $(60 \%)$ were in a good category. The need of Order (Order) in this study is defined as adolescents' need to organize things, maintain cleanliness and order. The results of data analysis through adolescents' answers on the questionnaire given that most teenagers have arranged their belongings, rarely borrow belongings from friends without permission. However, teenagers 
are still not used to carrying out activities with a plan. Factors that influence discipline/discipline come from the school environment and the environment. The school environment consists of the type of authoritarian teacher or school leadership who always dictates his will without paying attention to adolescents, making aggressive adolescents want to rebel against the restraints and inhuman treatment they receive so that orderly behavior does not appear.

The research results on psychological needs on the understanding component showed that most of the data $(52.3 \%)$ were insufficient categories. The analysis results on the answers of adolescents on the questionnaire already understood the condition of the orphanage. However, there were still many adolescents who were considered less mature by their caregivers. The need for Understanding (Understanding) in this study is to ask or answer general questions related to the situation of the orphanage ${ }^{12}$. This understanding is an advanced condition of adolescent knowledge about various things that exist in the orphanage. This understanding is needed so that adolescents have high self-acceptance of the existence of the orphanage. Self-acceptance will support the fulfillment of psychological needs, which impact the formation of a strong personality to live life and achieve goals.

The application of this group, the nursing intervention model, is proven to meet adolescents' psychological needs in the orphanage. Quantitatively, the $\mathrm{H} 0$ statistical test results are rejected, meaning that there are differences in psychological needs before and after the HIC-based group nursing intervention model is applied. Interviews with adolescents reinforced these test results at the orphanage, already feeling confident, willing to participate in community organization activities close to the orphanage, participating in mosque youth activities. Model simulation is carried out with assistance to the orphanage caregivers. The simulation is carried out for 2 (two weeks). Activities carried out by examining what teenagers feel while in the orphanage, their hopes, and aspirations, learning to identify the weaknesses and strengths that exist in each teenager, their talents, and the orphanage's proposed activities according to their talents. Teens are also provided with actions that can increase their self-confidence and reinforce positive behavior. Researchers also coordinate with the chairman of the Orphanage Communication Forum so that teenagers participate in the activities of the Youth Organization, Youth Mosque or other organizations. Van Dierendonck et al. (2008)explained that environmental control by controlling activities with the environment is one of the psychological indicators for adolescents in the orphanage.

The Model of Nursing Group Intervention application has been proven to fulfill adolescents' psychological needs in the Orphanage. Quantitative, statistical resulted in $\mathrm{H} 0$ rejected, which means there is a difference between the psychological need before and after Model of Nursing Group Intervention Simulation based on HIC. An interview session strengthened this result with adolescents in the Orphanage. The adolescent expressed a feeling of confidence and willingness to attend community organization activities near the Orphanage, such as mosque youth activities. This simulation was applied for two weeks, accompanied by assistance from caregivers. It's implemented by assessing what adolescents felt, hope, and ambition learned about identifying their strengths and weaknesses and their talent, which were continued by suggesting adolescents' activity program based on their talent during a stay in the Orphanage. Various actions and strategies also provide them to enhance the self-confidence and positive behavior strengthening. The researchershave coordinated with the Chief of Communication Forum. Thus, the adolescent participates in various Youth Organization, Mosque Youth, or other organizations. The ability to deal with the environmental situation by controlling activity is an adolescent psychological indicator in the Orphanage.

The limitation of this research to fulfill the Orphans' psychological needs is the process of Focus Group Discussion (FGD) that unable to perform but might change by the expert discussion. The person adjusts the member according to the plan of FGD. The result of the discussion revealed the appropriate content of research hopes and goals.

This Model of Nursing Group Intervention is recommended, especially for the community nurse who works in the Primary Health Care Services with a working area covering the Orphanage. It's also recommended to the Head of the Government Social Services of Surabaya City and Sidoarjo Regency as a substance to arrange the 
development program for adolescents in the Orphanage. This research proposes that the University with the Psychological Faculty resulted in an intensive counselor contribution for the Orphanage.

\section{Conclusions}

According to the results, the conclusion of this research was:

Model of Nursing Group Intervention based on Interpersonal Human Caring composed bymodel component composer consists of predisposing factors and caring values, supporting factors and caring environment, driving factors, and interpersonal human caring behavior. Predisposing factors and caring values are crucial factors to enhance interpersonal human caring behavior. The indicators of predisposing and caring values are attitude, motivation, and commitment of the Orphanage Administrator.

Supporting factors and a caring environment might strengthen the interpersonal human caring behavior. The supporting factors and caring environment are learning, social, counseling, and chance to develop accomplishment.Driving factors might increase interpersonal human caring behavior. The indicators of driving factors are a legal aspect of the Orphanage, family, and community support.Interpersonal human caring behavior is essential for the psychological needs of adolescent orphans. The indicators of interpersonal human caring are interpersonal communication, health education, caring intervention, and action to enhance self-confidence.

Model of Nursing Group intervention based on interpersonal human caring (IHC) can fulfill the adolescent orphans' psychological needs. This model might enhance attitude, motivation, administrator commitment, driving factors and environmental caring, and interpersonal human caring (IHC) behavior.

\section{Appreciations}

Gratitude and appreciation for cooperation and support in finishing this research delivered to the orphans who have been willing to become respondents in this research. The Orphanage Administrators and the Head of Orphanage Federation all-around Surabaya City and Sidoarjo Regency. The Government Social Services of Surabaya City and Sidoarjo Regency. Polytechnic of Health, Health Ministry Of Surabaya as funding resource, mainly through the Central Research and Community

Ethical Clearance: Ethical clearance this study from the Research Ethics Commission of Politeknik Kesehatan Kemenkes Surabaya No. 183/5 / KEPK / VI / 2018.

Conflict of Interest: The authors declare that they have no competing interest

Funding: No funding was available for this study

\section{References}

1. Wulandari RHL, Rola F. Konsep Diri Dan Motivasi Berprestasi Remaja Penghuni Panti Asuhan. J Pemberdaya Komunitas. 2004;3 (2):74-80.

2. Mohammad A. Psikologi Remaja. Bumi Aksara; 2006.

3. Pamjaki. Undang-Undang Republik Indonesia Nomor 38 Tahun 2014 tentang Keperawatan. 2014.

4. Ali M, Asrori. Psikologi Remaja, Perkembangan Peserta Didik. Jakarta: Bumi Aksara; 2008.

5. Prabadewi KDL, Widiasavitri PN. Hubungan Konsep Diri Akademik dengan Motivasi Berprestasi pada Remaja Awal yang Tinggal di Panti Asuhan di Denpasar. J Psikol Udayana. 2014;1(2):261-70.

6. Widiasavitri IART dan PN. Pada Remaja Awal Di Panti Asuhan Kota Denpasar. Pendidikan. 2016;3(3):542-50.

7. Suryo BD. Pengaruh Gaya Kepemimpinan Transformasional, Budaya Organisasi dan Inovasi terhadap Kinerja (Studi pada Panti Asuhan di Kota Tomohon dan Kabupaten Minahasa). J Apl Manaj. 2010;8(2).

8. Kementerian Sosial Republik Indonesia. Peraturan Menteri Sosial Republik Indonesia Nomor : 30 / Huk / 2011 Tentang Standar Nasional Pengasuhan Anak Untuk Lembaga Kesejahteraan Sosial Anak. 2011.

9. Bartholomew KJ, Ntoumanis N, Ryan RM, Bosch JA, Thøgersen-Ntoumani C. Self-Determination Theory and Diminished Functioning. Personal Soc Psychol Bull. 2011 Nov;37(11):1459-73. 
10. Alligood MR. Nursing Theorists and Their Work. Elsevier Mosby. 2014;

11. van Dierendonck D, Díaz D, Rodríguez-Carvajal R, Blanco A, Moreno-Jiménez B. Ryff's Six-factor Model of Psychological Well-being, A Spanish Exploration. Soc Indic Res. 2008 Jul;87(3):473-9.

12. Hall CS, Lindzey G. Psikologi Kepribadian I Teoriteori Psikodinamik (Klinis). Yogyakarta: Kanisius; 1993.

13. Hurlock, Brown EE. Psikologi Perkembangan Suatu Pendekatan Sepanjang Rentang Kehidupan. Erlangga; 2007.

14. Kuntoro H. Metode sampling dan penentuan besar sampel. Surabaya: Pustaka Melati. 2010;

15. Chin. Modern methods for business research. London: Psychology Press.; 1998.

16. Ferris KR. Organizational commitment and performance in a professional accounting firm. Accounting, Organ Soc. 1981;6(4):317-25.

17. Meyer JP, Allen NJ. Commitment in the Workplace: Theory, Research, and Application. New York: Sage Publication, Inc; 1997.
18. Kashefi M, Adel RM, Rahimi H, Abad G, Aliklayeh BH, Keshavarz MH, et al. Organizational Commitment and Its Effects on Organizational Performance. Interdiscip J Contemp Res Bus. 2013;2(12):501-10.

19. Bontis N, Fitz-enz J. Intellectual capital ROI: A causal map of human capital antecedents and consequents. J Intellect Cap. 2002;3(3):223-47.

20. Widyastuti Y, Anita R, Yuliasti EP. Kesehatan Reproduksi. Yogyakarta: Fitramaya; 2009.

21. Santrock W. Life-Span Development: Perkembangan Masa Hidup. Jakarta: Erlangga; 2002.

22. Bartholomew KJ, Ntoumanis N, Ryan RM, Bosch JA, Thøgersen-Ntoumani C. Self-determination theory and diminished functioning: The role of interpersonal control and psychological need thwarting. Personal Soc Psychol Bull. 2011;37(11):1459-73.

23. Sheldon KM, Bettencourt BA. Psychological needsatisfaction and subjective well-being within social groups. Br J Soc Psychol. 2004;4(1). 